\title{
SYSTEMATIC REVIEW OF CHILD ABUSE PERPETRATORS WORLDWIDE: CHARACTERISTICS AND RISK FACTORS
}

\author{
Hanani Nabilah $M S^{1}$, Noor Dalila IZA ${ }^{1}$, and Faiz $D^{1}$. \\ ${ }^{1}$ Department of Community Health, UKM Medical Centre, Universiti Kebangsaan Malaysia, 56000 Cheras, Kuala Lumpur, \\ Malaysia
}

Correspondence:

Dr. Faiz Daud

Department of Community Health,

UKM Medical Centre,

56000 Cheras, Kuala Lumpur, Malaysia

Email: faizdaud@ppukm.ukm.edu.my

\begin{abstract}
Child abuse is a part of violence and maltreatment towards a child. It has led to many immediate and longterm consequences. The factors pertaining to the perpetrators of physical and emotional abuse were least explored in the literature. The aim of this systematic review is to comprehend the factors of vulnerability among the perpetrators of child abuse, and to identify the most common reported characteristics of child abuse perpetrators in the literature globally. A systematic search of articles published between 2013 and 2018 was conducted in several databases (Scopus, Ovid Medline, EBSCOhost and Google Scholar). Fourteen studies met the inclusion criteria and were included in the review. The risk factors and characteristics of child abuse perpetrators are classified into three different levels; individual, relationship and community. The most common reported characteristics are at the individual level. Family background plays an important role in determining the risk of being a child abuse perpetrator. Low socioeconomic status of the family is the prominent contributing risk factor for abusing own children.
\end{abstract}

Keywords: child abuse, characteristics, perpetrator

\section{Introduction}

Child abuse is a part of violence and maltreatment towards a child (1). There are various types of child abuse that caught attention currently. Few types of child abuse are listed, such as domestic abuse, sexual abuse, neglect, online abuse, physical abuse, emotional abuse, child sexual exploitation, female genital mutilation, bullying and cyberbullying, child trafficking, grooming and harmful sexual behaviour. Cyberbullying, mostly affect the girls as they are more vulnerable and is significantly related to the child sexual abuse (2). All of these have led to many immediate and long-term consequences. Not to mention physical injury, disability and death, it can also impair brain development, causing reduced cognitive function and mental health problems (1). In some extent, children who experienced abuse would revictimized other children when they are older.

Many studies have been carried out in addressing the issue of child abuse. It is a major and serious public health problem as it contributes to health, economic and social burden globally. In year 2016, there were 3,061 cases of child abuse reported by Department of Social Welfare Malaysia (3). However, this figure did not reveal the true number of child abuse cases as there were unreported cases in the society due to some barriers (4). A study by Fang et al. (5) showed that the lifetime cost of a nonfatal abuse victim is approximately RM864,000 and RM5,234,000 for a fatal abuse victim. This finding is supported by the data from Centers for Disease Control and Prevention (CDC) where the total lifetime economic cost of child abuse and neglect is estimated at RM510 billion each year (6). The lifetime cost includes cost for short term healthcare, long term medical care, productivity losses, child welfare, criminal justice and special education.

Previous systematic reviews discussed on the impact of child abuse and its prevention (7-9). Most of them focused on the victims of child abuse (10-12). On the other hand, the perpetrator is less often studied. As child abuse has become a current significant public health issue, it is important to be able to identify and recognize the characteristics of the child abuse perpetrators. Hence, this review will investigate the factors of perpetrator causing physical and emotional abuse, which are least explored in the literature. The aim 
of this systematic review is to comprehend the factors of vulnerability among the perpetrators of child abuse, and to identify the most common reported characteristics of child abuse perpetrators in the literature globally based on published articles for the past 5 years.

\section{Methods}

\section{Literature Search}

We carried out systematic search for relevant published articles using four major search engines namely Scopus, Ovid Medline, EBSCOhost and Google Scholar. In order to yield the most current studies, we restricted retrieval to articles published from year 2013 to 2018 . We performed our systematic review using the PRISMA checklist (13) for the workflow of publications search as presented in Figure 1. The four major selected databases were accessed using the keywords "child abuse" OR "child violence" $A N D$ "perpetrator" $O R$ "caretaker" $O R$ "parent" $A N D$ "risk factor" OR "characteristic" AND NOT "sexual". For the articles identified from the database searched, we discarded articles that were duplicated in search engines before we screened them. We screened the titles and abstracts which were relevant to our research questions and any articles that appeared to help us provide an answer to our research questions were included. The total number of articles left after completing the screening were assessed for availability of full text. Full text articles subsequently were retrieved and evaluated based on inclusion and exclusion criteria. Inclusion criteria were: (a) sample population from the community which consisted of parents or caretakers of children aged $0-18$ years old with/ without their own children aged $0-18$ years old OR parents or caretakers who were under detention/charged for child abused crime, (b) tools used in assessing child abuse risk were validated or using retrospective legal record, (c) included studies that were done all over the world. The studies were excluded on the basis of (a) lack of empirical data (i.e., no correlation analysis), (b) qualitative studies. Studies were also excluded if the English version of the full text was not available. A total of four electronic database searches revealed a total number of fourteen articles for review (Table 1). The reviewers for these selected articles were two candidates of Masters of Public Health Program, Universiti Kebangsaan Malaysia.
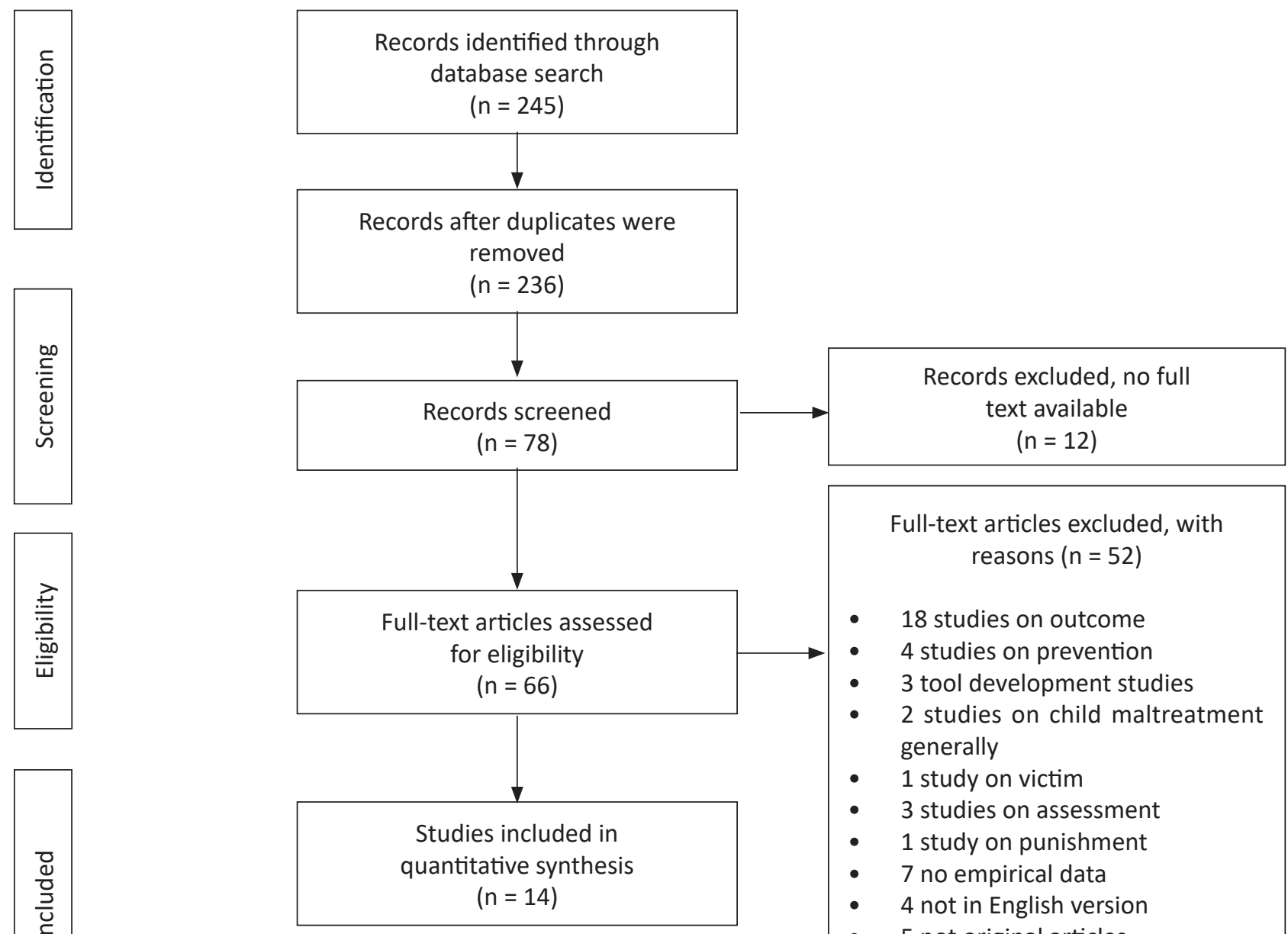

Full-text articles excluded, with reasons $(n=52)$

- 18 studies on outcome

- 4 studies on prevention

- 3 tool development studies

- 2 studies on child maltreatment generally

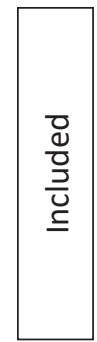

- 1 study on victim

- 3 studies on assessment

- 1 study on punishment

- 7 no empirical data

- 4 not in English version

- 5 not original articles

- 2 no validation tool

- 2 qualitative studies

Figure 1: Workflow showing process of articles selection for the review 
Table 1: Characteristics of studies reviewed

\begin{tabular}{|c|c|c|c|c|c|}
\hline Author & Study Population & $\begin{array}{l}\text { Study } \\
\text { Design }\end{array}$ & Tool(s) & Risk factor/ characteristic & Outcome \\
\hline Cetin (14) & $\begin{array}{l}158 \text { parents with } \\
\text { children aged 0-6 years } \\
\text { who resided in the city } \\
\text { center of the province of } \\
\text { Duzce, Turkey during the } \\
\text { spring semester of the } \\
2014-2015 \text { academic } \\
\text { year }\end{array}$ & $\begin{array}{l}\text { Cross } \\
\text { sectional }\end{array}$ & $\begin{array}{l}\text { Child Abuse Potential } \\
\text { Inventory (CAPI) }\end{array}$ & $\begin{array}{l}\text { Age and gender of parents, } \\
\text { number of residents in the } \\
\text { house, place of residence, } \\
\text { income of family }\end{array}$ & $\begin{array}{l}\text { Child abuse } \\
\text { risk score }\end{array}$ \\
\hline $\begin{array}{l}\text { Ling \& Kwok } \\
\text { (15) }\end{array}$ & $\begin{array}{l}978 \text { parents and } 542 \\
\text { children ( } 9-13 \text { years } \\
\text { old) recruited from } 565 \\
\text { families from six schools } \\
\text { from the three main } \\
\text { districts of Hong Kong }\end{array}$ & $\begin{array}{l}\text { Cross } \\
\text { sectional }\end{array}$ & $\begin{array}{l}\text { Childhood abuse and } \\
\text { trauma scale } \\
\text { Asian American values } \\
\text { scale-multidimensional } \\
\text { scale } \\
\text { Relationship dynamic scale } \\
\text { Inventory of parent and } \\
\text { peer attachment } \\
\text { Parent-child conflict tactics } \\
\text { scale (CTSPC) }\end{array}$ & $\begin{array}{l}\text { Chinese cultural parenting } \\
\text { values, parents' childhood } \\
\text { abuse history, parent- } \\
\text { child attachment, marital } \\
\text { conflict }\end{array}$ & $\begin{array}{l}\text { Child abuse } \\
\text { risk score }\end{array}$ \\
\hline $\begin{array}{l}\text { Rodriguez et } \\
\text { al. (16) }\end{array}$ & $\begin{array}{l}70 \text { male intimate partner } \\
\text { violence perpetrators } \\
\text { in Spain who were } \\
\text { court ordered to an } \\
\text { intervention program for } \\
\text { domestic violence }\end{array}$ & $\begin{array}{l}\text { Cross } \\
\text { sectional }\end{array}$ & $\begin{array}{l}\text { State-Trait Anger Expression } \\
\text { Inventory-2 } \\
\text { Plutchick Impulsivity Scale } \\
\text { Interpersonal Reactivity } \\
\text { Index } \\
\text { Reading the Mind in the } \\
\text { Eyes Test Revised } \\
\text { Parent-Child Aggression } \\
\text { Acceptability Movie Task } \\
\text { Attitudes Toward Spanking } \\
\text { Discipline Questionnaire } \\
\text { Parent Child Vignettes } \\
\text { Child Abuse Potential } \\
\text { Inventory } \\
\text { Adult-Adolescent Parenting } \\
\text { Inventory-2 }\end{array}$ & $\begin{array}{l}\text { Anger, impulsivity as } \\
\text { an immediate reaction, } \\
\text { empathy, emotional } \\
\text { recognition abilities } \\
\text { related to empathy, } \\
\text { parent child aggression, } \\
\text { physical discipline believes, } \\
\text { attitudes toward physical } \\
\text { punishment }\end{array}$ & $\begin{array}{l}\text { Child abuse } \\
\text { risk score }\end{array}$ \\
\hline $\begin{array}{l}\text { Rodriguez, \& } \\
\text { Tucker (17) }\end{array}$ & $\begin{array}{l}95 \text { maternal caregivers } \\
\text { of } 6-9 \text { years old children } \\
\text { from various community } \\
\text { sites, including day care } \\
\text { centres and after school } \\
\text { programs in United State }\end{array}$ & $\begin{array}{l}\text { Cross } \\
\text { sectional }\end{array}$ & $\begin{array}{l}\text { Child Abuse Potential } \\
\text { Inventory } \\
\text { Adult-Adolescent Parenting } \\
\text { Inventory-2 } \\
\text { Parent Perception Inventory } \\
\text { Child Vignettes } \\
\text { Empathy Quotient-Short } \\
\text { Interpersonal Reactivity } \\
\text { Index } \\
\text { Perceived Stress Scale } \\
\text { Daily Hassles and Uplifts } \\
\text { Scale } \\
\text { Mental Health Inventory-5 } \\
\text { Loneliness Scale } \\
\text { Social Support Resources } \\
\text { Index }\end{array}$ & $\begin{array}{l}\text { Empathy, distress, social } \\
\text { support }\end{array}$ & $\begin{array}{l}\text { Child abuse } \\
\text { risk score }\end{array}$ \\
\hline $\begin{array}{l}\text { Mikaeili et al. } \\
\text { (18) }\end{array}$ & $\begin{array}{l}893 \text { male students aged } \\
12 \text { to } 14 \text { years with their } \\
\text { parents selected from } \\
\text { school in Iran }\end{array}$ & $\begin{array}{l}\text { Cross } \\
\text { sectional }\end{array}$ & $\begin{array}{l}\text { Childhood Trauma } \\
\text { Questionnaire } \\
\text { Modified Adult Attachment } \\
\text { Questionnaire } \\
\text { Revised Scale of Symptoms } \\
\text { Checklist } 90 \\
\text { Beck Depression Inventory, } \\
\text { II } \\
\text { State Trait Anxiety Inventory }\end{array}$ & $\begin{array}{l}\text { Parent-child attachment } \\
\text { style, general psychiatric } \\
\text { symptomatology, parental } \\
\text { depression, parental } \\
\text { temporary condition of } \\
\text { state anxiety and parental } \\
\text { long standing } \\
\text { quality of trait anxiety }\end{array}$ & $\begin{array}{l}\text { Child abuse } \\
\text { risk score }\end{array}$ \\
\hline
\end{tabular}




\begin{tabular}{|c|c|c|c|c|c|}
\hline Author & Study Population & $\begin{array}{l}\text { Study } \\
\text { Design }\end{array}$ & Tool(s) & Risk factor/ characteristic & Outcome \\
\hline $\begin{array}{l}\text { Rodriguez } \\
\text { (19) }\end{array}$ & $\begin{array}{l}\text { Community sample } \\
\text { of } 135 \text { mother-child } \\
\text { (4-9 years old) dyads } \\
\text { recruited for two } \\
\text { separate parenting } \\
\text { studies in two regions of } \\
\text { the United States }\end{array}$ & $\begin{array}{l}\text { Cross } \\
\text { sectional }\end{array}$ & $\begin{array}{l}\text { Matching Affect to Child } \\
\text { Task } \\
\text { Interpersonal Reactivity } \\
\text { Index } \\
\text { Plotkin Child Vignettes } \\
\text { Child Abuse Potential } \\
\text { Inventory } \\
\text { Adult-Adolescent Parenting } \\
\text { Inventory-2 }\end{array}$ & Empathy & $\begin{array}{l}\text { Child abuse } \\
\text { risk score }\end{array}$ \\
\hline $\begin{array}{l}\text { Van Vliet- } \\
\text { Ruissen et al. } \\
\text { (20) }\end{array}$ & $\begin{array}{l}206 \text { women in New } \\
\text { Zealand engaged in a } \\
\text { child abuse prevention } \\
\text { programme for mothers } \\
\text { who are highly socially } \\
\text { disadvantaged, and at } \\
\text { high risk for child abuse } \\
\end{array}$ & $\begin{array}{l}\text { Cross } \\
\text { sectional }\end{array}$ & $\begin{array}{l}\text { Historical data collected } \\
\text { (retrospective record) }\end{array}$ & $\begin{array}{l}\text { Mother with history of } \\
\text { traumatic brain injury }\end{array}$ & $\begin{array}{l}\text { Risk for child } \\
\text { abuse }\end{array}$ \\
\hline $\begin{array}{l}\text { Ben-David } \\
(21)\end{array}$ & $\begin{array}{l}231 \text { court rulings in } \\
\text { Israel that discussed } \\
\text { whether parental rights } \\
\text { should be terminated } \\
\text { or not }\end{array}$ & $\begin{array}{l}\text { Cross } \\
\text { sectional }\end{array}$ & $\begin{array}{l}\text { Court rulings (retrospective } \\
\text { data) }\end{array}$ & $\begin{array}{l}\text { Demographic features } \\
\text { (age, employment), Marital } \\
\text { status of the parents, } \\
\text { Mental health problems, } \\
\text { Criminal background, } \\
\text { Parent-child relationship }\end{array}$ & Child abuse \\
\hline $\begin{array}{l}\text { Douki et al. } \\
\text { (22) }\end{array}$ & $\begin{array}{l}562 \text { mothers with the } \\
\text { last child aged } 1 \text { month } \\
\text { to } 12 \text { years old referred } \\
\text { to children's referral } \\
\text { hospital, for healthcare } \\
\text { services for their } \\
\text { children in Iran }\end{array}$ & $\begin{array}{l}\text { Cross } \\
\text { sectional }\end{array}$ & $\begin{array}{l}\text { Conflict Tactics Scale for } \\
\text { Parent and Child } \\
\text { Spielberger State-Trait } \\
\text { Anxiety Inventory }\end{array}$ & $\begin{array}{l}\text { Mothers' age } \\
\text { Mothers' education } \\
\text { Number of children } \\
\text { Mothers' marital status } \\
\text { Exposure of mothers to } \\
\text { maltreatment during } \\
\text { childhood } \\
\text { Maternal anxiety }\end{array}$ & $\begin{array}{l}\text { Child abuse } \\
\text { risk score }\end{array}$ \\
\hline $\begin{array}{l}\text { Zimmer } \\
\text { Gembeck et } \\
\text { al. (23) }\end{array}$ & $\begin{array}{l}261 \text { female caregivers } \\
\text { and their children } \\
\text { aged } 2.5 \text { to } 7.2 \text { years in } \\
\text { Australia }\end{array}$ & $\begin{array}{l}\text { Cross } \\
\text { sectional }\end{array}$ & $\begin{array}{l}\text { Child Behavior Checklist } \\
\text { Beck Depression } \\
\text { Inventory-II } \\
\text { Child Abuse Potential } \\
\text { Inventory }\end{array}$ & $\begin{array}{l}\text { Maternal emotional } \\
\text { distress } \\
\text { Observed maternal } \\
\text { sensitivity }\end{array}$ & $\begin{array}{l}\text { Child abuse } \\
\text { risk score }\end{array}$ \\
\hline $\begin{array}{l}\text { Abdullah MQ } \\
(24)\end{array}$ & $\begin{array}{l}550 \text { students in primary } \\
\text { schools of Aleppo City } \\
\text { (Syria) aged between } \\
10-15 \text { years }\end{array}$ & $\begin{array}{l}\text { Cross } \\
\text { sectional }\end{array}$ & $\begin{array}{l}\text { Family Violence / Child } \\
\text { Abuse Survey (Fv-Cas) }\end{array}$ & $\begin{array}{l}\text { The parents past history } \\
\text { Present life situation } \\
\text { Life stressors } \\
\text { Psychological } \\
\text { characteristics }\end{array}$ & $\begin{array}{l}\text { Child abuse } \\
\text { risk score }\end{array}$ \\
\hline $\begin{array}{l}\text { Price-Wolf } \\
(25)\end{array}$ & $\begin{array}{l}\text { 3,023 parent } \\
\text { respondents in } 50 \\
\text { California cities }\end{array}$ & $\begin{array}{l}\text { Cross } \\
\text { sectional }\end{array}$ & $\begin{array}{l}\text { Interpersonal Support } \\
\text { Evaluation List } \\
\text { Project on Human } \\
\text { Development in Chicago } \\
\text { Neighborhoods community } \\
\text { survey } \\
\text { Parent-Child Conflict Tactics } \\
\text { Scale }\end{array}$ & $\begin{array}{l}\text { Parents' gender } \\
\text { Parental age } \\
\text { Race/ethnicity } \\
\text { Type and quantity of social } \\
\text { support } \\
\text { Collective efficacy }\end{array}$ & $\begin{array}{l}\text { Child abuse } \\
\text { risk score }\end{array}$ \\
\hline $\begin{array}{l}\text { Freisthler } \\
(26)\end{array}$ & $\begin{array}{l}\text { 3,023 parent } \\
\text { respondents in } 50 \\
\text { California cities }\end{array}$ & $\begin{array}{l}\text { Cross } \\
\text { sectional }\end{array}$ & $\begin{array}{l}\text { Parent-Child Conflict Tactics } \\
\text { Scale } \\
\text { Primary Care Evaluation of } \\
\text { Mental Disorders } \\
\text { Dickman Dysfunctional } \\
\text { Impulsivity Scale }\end{array}$ & $\begin{array}{l}\text { Parents gender } \\
\text { Parental age } \\
\text { Number of children } \\
\text { Depressive symptoms } \\
\text { Anxiety symptoms } \\
\text { Frequency of drinking } \\
\text { venue utilization } \\
\text { Dose-response for drinking } \\
\text { venues }\end{array}$ & $\begin{array}{l}\text { Child abuse } \\
\text { risk }\end{array}$ \\
\hline
\end{tabular}




\begin{tabular}{|l|l|l|l|l|l|}
\hline Author & Study Population & $\begin{array}{l}\text { Study } \\
\text { Design }\end{array}$ & Tool(s) & Risk factor/ characteristic & Outcome \\
\hline $\begin{array}{l}\text { Romero- } \\
\text { Martínez (27) }\end{array}$ & $\begin{array}{l}\text { 920 parents randomly } \\
\text { selected in five public } \\
\text { elementary schools } \\
\text { of Northern Portugal } \\
\text { (National Representative } \\
\text { Study of Psychosocial } \\
\text { Context of Child Abuse } \\
\text { and Neglect in Portugal) }\end{array}$ & $\begin{array}{l}\text { Cross } \\
\text { sectional }\end{array}$ & $\begin{array}{l}\text { Childhood History } \\
\text { Questionnaire } \\
\text { Child Abuse Potential } \\
\text { Inventory (CAPI) }\end{array}$ & $\begin{array}{l}\text { History of childhood } \\
\text { physical abuse among } \\
\text { parents (gender and } \\
\text { timing) }\end{array}$ & $\begin{array}{l}\text { Child abuse } \\
\text { risk score }\end{array}$ \\
\hline
\end{tabular}

Classification for Risk Factors/Characteristics of Child Abuse Perpetrators

We classified the identified various risk factors and characteristics of perpetrators that have been extracted from the studies into three main groups (24). So far, there are no available established classification by high-end global association for this topic. The three categories of risk factors and characteristics are (a) Individual level, (b) Relationship level, (c) Community level.

\section{Results}

\section{Characteristics of Studies from year 2013 to 2018}

As mentioned in the methodology section, the systematic review included studies from year 2013 to 2018 from various countries in the world, prominently from the West. There were two approaches to the study design, however quantitative approach dominated in this search. All the studies used observational type of quantitative study, namely cross sectional. Out of fourteen studies, twelve had adopted existing validated child abuse risk scale and validated risk factors and characteristics of perpetration in their survey. Two studies used retrospective record from legal documents. Majority of sample population from the community consisted of parents or caretakers of children aged 0-18 years old with/without their own children aged 0-18 years old. Only two studies included parents or caretakers that had been under detention or charged for child abused crime. The sample size ranged from $n=70$ to $n=3023$. The identified risk factors and characteristics of perpetration in the studies were further classified into three main categories.

\section{Characteristics/Risk Factors of Child Abuse Perpetrator}

\section{Individual Level}

The risk factors and characteristics identified at individual level were demographic profile (family income), prior history of being abused during childhood, parental mental health, alcohol consumption and dependence with impulsivity tendency, life stressors and empathy. Eight of the studies significantly demonstrated risk factors and characteristics of child abuse perpetration at individual level. Parents with low family income had a significantly higher risk for abusing their children than other level of income $(14,17)$. Abdullah $(24)$ found that parents with childhood history of being abused tend to abuse their children. This was supported by Romero-Martínez et. al. (27) which demonstrated that parents with a history of childhood physical abuse showed higher Child Abuse Potential Inventory (CAPI) score than parents without history of childhood physical abuse. Mikaeili et al. (18) and Douki et al. (22) both agreed that parental anxiety contributed to child abuse. In addition, Ben-David (21) found that mothers who suffered from mental health problems such as personality disorder and intellectual disability had higher risk for abusing their children. Alcohol consumption and dependence by parents had a higher risk to adopt physically abusive parenting practices compared to non-alcoholic parents as demonstrated by Freisthler, \& Gruenewald (26). Other than a history of childhood abuse, Abdullah (24) also found that present-past life stressors for parents (low job status of father, mother-child separation, and serious childhood trouble for the mother) had a significantly higher risk of abusing their children. Poor emphatic ability towards child was also found to be significantly related with greater risk of physical child abuse and this systematic review found abovementioned characteristic in two of the studies namely by Rodriguez (19) and Rodriguez, \& Tucker (17).

\section{Relationship Level}

Characteristics and risk factors of child abuse perpetration at relationship level described risk factors and characteristics that derived from relationship complication between parents and their children or between parents (mother and father). The risk factors and characteristics identified in this category were marital status/conflict, low social support, and parents-child relationship. Six of the studies significantly demonstrated risk factors and characteristics of child abuse perpetration at relationship level. Two of the studies demonstrated that low social support from family members was significantly associated with higher risk of child abuse $(17,25)$. Rodriguez \& Tucker (17) further extended their study to examine the interaction between level of parents' distress and social support on abuse risk. 
They found that parents with high distress but low social support obtained the highest abuse risk scores. Two of the studies demonstrated that marital conflict and parents' marital status were significantly associated with child abuse $(15,17)$. Marital conflict significantly leads to higher risk of abusing the child (15). In this study, they also demonstrated that Chinese cultural values among parents strengthened the negative effect of marital conflict on child abuse. The study described Chinese cultural values as a set of core traditional values on parenting, such as family recognition, conformity, collectivism and humility. While Rodriguez \& Tucker (17) found that single mothers obtained significantly higher abuse risk scores in CAPI, two other studies showed that mother's marital status (either married or single) was not associated with child abuse $(21,22)$. Four of the studies demonstrated that parents who were having issue with child-parent relationship would significantly obtain higher risk of child abuse score $(15,16,18,21)$. Parents of children in the abuse group were more likely to be assessed as lacking parental responsiveness ability compare to nonabuse group (21). Anxious-ambivalent attachment and avoidant attachment type of child-parent relationship were found to play a significant role in predicting emotional and physical abuse of a child (18). Low parent-child attachment was significantly associated with a high risk of child abuse (15). In this study, Ling \& Kwok (15) further demonstrated that Chinese cultural parenting values will increase child abuse when parent-child attachment is low and decrease child abuse when parent-child attachment is high. Greater approval of parent-child aggression significantly increased child abuse risk (16). This parent-child relationship was contributed by physical discipline believes and attitudes toward physical punishment by parents.

\section{Community Level}

Characteristics and risk factors of child abuse perpetration at community level described external factors or features of child abuse perpetrator that influenced them to be abusive. The risk factors and characteristics identified in this category were number of residents in the house and place of residence and collective efficacy (neighbourhood support). Three of the studies significantly demonstrated risk factors and characteristics of child abuse perpetration at community level $(14,22,25)$. Parents who stayed with six or more number of people in the house, in a small town or village had a significantly higher risk for abusing their child (14). Douki et al. (22) also agreed that large families with a number of children more than five was significantly associated with a higher risk of physical abuse towards children. Price-Wolf (25) found that low level of emotional support by community was associated with physical abuse by both mother and father. Collectivism is an example of a person's perceptions of the quality of neighbourhood social relationship and it is believed to differ between genders (25). Low level of collectivism may strongly associate with negative outcomes for mother than father (28) including child abuse (29). However, Price-Wolf (25) demonstrated that collectivism was not significantly correlated with risk of child abuse.

\section{Discussion}

The results obtained in this systematic review indicate that family background and situation play important roles in determining the risks of being a child abuse perpetrator. The characteristics of a perpetrator were based on 3 levels: individual, relationship and community. Since decades ago, the characteristics of a child abuse perpetrator have been classified into different categories $(30,31)$. Nevertheless, they still fall into similar context of classification across the diverse groups of characteristics.

Individual level explains the internal factors of the perpetrator, including socioeconomic status of the family, history of childhood abuse, mental health status and presence of life stressors. The perpetrators with prior history of childhood abuse and low socioeconomic status were the most common reported risk factors and characteristics in the four studies at individual level. Over decades, low family income had been recognized as a risk factor for child abuse by previous traditional researchers (32-34) and this particular risk factor remains the most frequent factor of child abuse reported in the current literature. History of childhood abuse is also found to be the most reported significant risk factor contributing to physical abuse. One of the well-known hypotheses that supported this risk factor of history of childhood abuse was intergenerational transmission (35). The intergenerational transmission describes parents who were abused during childhood tend to physically abuse their children. The intergenerational hypothesis is a prominent belief with a paucity of empirical evidence, supports the transmission formulation in the child abuse studies since decades ago (36). In their literature review, Kaufman \& Zingler (36) critically demonstrated various empirical studies with numerous methodological variation in order to provide substantive evidence. They found that approximately onethird of all individuals who were physically abused, sexually abused or extremely neglected subjected their off-springs to one of these forms of maltreatment, while the remaining two-thirds provided adequate care for their children. In the current literature, the hypothesis, intergenerational transmission of child abuse was studied by Widom et al. (37). In this study, parents with child abuse history were more likely to neglect their children, rather than abusing them. However, this finding may be inaccurate as the data came from a single source. In addition, parents with mental illness and substance abuse and social problems were strongly related to child abuse and neglect (38).

Relationship level such as marital conflict and parentchild relationship were also ascertained as risk factors for child physical abuse. Low parents-child attachment was significantly associated with physical abuse. This risk factor has been reported since decades ago in previous literatures which had demonstrated evidences of highly aversive pattern of parent-child interaction displayed by abusive parents. Abusive parents had poor interaction with their children (30). Evidence of abusive parents that interacted less and provided less support towards their children were found in the studies since early 1980s $(39,40)$. Earlier 
studies also demonstrated that abusive parents were found to be engaged in a negative interaction with their children. As for marital conflict, physical abuse victims were found to come from broken family. The definite problems in child abuse cases usually involved divorce, parental separation and family disharmony (41).

Finally, community level also plays a role in influencing the perpetrators' characteristics. This category of child abuse perpetrator characteristics was supported by the sociological model of child abuse that has been growing in interest since early 1970s. The sociological model of child abuse posited social factors as being responsible for child abuse occurrence such as social isolation and large family size (42). Undesirable neighbourhood conditions such as poverty, high crime rate and unstructured housing area often contributed to the child abuse. Sampson et al. (43) suggested that collective efficacy, defined as the social unity of the neighbourhood and willingness to engage in social control, can prevent crime and violence. Living in the community with collective efficacy is a protective factor against child abuse. Another risk factor in child abuse is parenting culture. A study has demonstrated that Chinese family has hierarchical relationship between parents and children as parents hold the authority to discipline their children. Parents believed that physical technique is a typical disciplinary practice (44). When a child is perceived as misbehaving, the parents often use physical technique to give a lesson to the child. It was the common disciplinary practices from generations to generations, and thus was considered non-abusive and socially acceptable.

\section{Conclusion and Recommendation}

The review indicates that various factors and characteristics of child abuse perpetration were found to be significantly associated with risk of abusing the child. Factors and characteristics of child abuse perpetration at the individual level were mostly reported in the review. However, the impacts of the other two categories vary considerably. By recognizing the risk factors and characteristics of child abuse perpetration in the review, it may encourage better identification of those at risk at primary care setting, followed by targeting prevention and intervention based on the risk factors identified. We found that low socioeconomic status of the family is the contributing risk factor for child abuse. Parents with low income, marital conflict, history of being abused during childhood, experience mental health problem and inappropriate consumption of alcohol tend to become abusive to their children. Primary care practitioners need to play an important role when identifying parents with mental health problems and they should be referred and managed accordingly to reduce the risk of being child abusers.

From this review we also found that many studies were done in the West with limited studies conducted in Asia. Our review comprises current articles from year 2013 to 2018 , thus other significant findings of studies in previous aforementioned years are not emphasized in this review.

\section{Acknowledgements}

The authors would like to thank the Universiti Kebangsaan Malaysia (UKM) for providing research grant, GUP-2017061. The authors would also like to acknowledge Ministry of Health Malaysia for scholarship award under the Hadiah Latihan Persekutuan 2017.

\section{Competing interests}

The authors declared no potential conflicts of interest with respect to the research, authorship and/or publication of this article.

\section{Authors' contribution}

Hanani Nabilah Mohd Sobri and Noor Dalila Inche Zainal Abidin had the primary responsibility of analysing and interpreting the data and drafting the manuscript. Faiz Daud initiated the research and reviewed the manuscript. All authors had read and approved the final manuscript.

\section{References}

1. World Health Organization (WHO). Child maltreatment (child abuse).https://www.who.int/violence_injury_ prevention/violence/child/en/. Accessed May 2, 2018.

2. Hébert $M$, Cénat JM, Blais $M$, Lavoie $F$, Guerrier M. Child Sexual Abuse, Bullying, Cyberbullying, and Mental Health Problems Among High Schools Students: A Moderated Mediated Model. Can Institutes Heal Res. 2017;33(7):623-29.

3. Kementerian Pembangunan Wanita, Keluarga dan Masyarakat. Laporan Statistik Jabatan Kebajikan Masyarakat 2016.

4. Harper CA, Perkins C. Reporting Child Sexual Abuse within Religious Settings: Challenges and Future Directions. Child Abuse Rev. 2018;27:30-41.

5. Fang X, Brown DS, Florence CS, Mercy JA. The economic burden of child maltreatment in the United States and implications for prevention. Child Abuse Negl. 2012;36(2):156-65.

6. Centers for Disease Control and Prevention (CDC). Child Abuse and Neglect Prevention. https://www. cdc.gov/violenceprevention/ childabuseandneglect/ index.html. Accessed March 3, 2019.

7. Alsehaimi A. A Systematic Review of Literature on Child Sexual Abuse in Saudi Arabia. J Child Dev Disord. 2016;02(02):1-5.

8. Norman RE, Byambaa M, De R, Butchart A, Scott J, Vos T. The Long-Term Health Consequences of Child Physical Abuse, Emotional Abuse, and Neglect: A Systematic Review and Meta-Analysis. PLoS Med. 2012;9(11):e1001349.

9. Mikton C, Butchart A. Child maltreatment prevention: A systematic review of reviews. Bull World Health Organ. 2009;87(5):353-61.

10. Domhardt M, Munzer A, Fegert JM, Goldbeck L. Resilience in Survivors of Child Sexual Abuse :A 
Systematic Review of the Literature. Trauma Violence Abuse. 2015;16(4):476-93.

11. Stoltenborgh $\mathrm{M}$, Bakermans-kranenburg MJ, Alink LRA, Ijzendoorn MH. The Prevalence of Child Maltreatment across the Globe : Review of a Series of Meta-Analyses. Child Abus Rev. 2015;24:37-50.

12. Hughes K, Bellis MA, Hardcastle KA, Sethi D, Butchart A, Mikton $C$, et al. The effect of multiple adverse childhood experiences on health : a systematic review and meta-analysis. Lancet Public Health. 2017;2(8):e356-e366.

13. Moher D, Shamseer L, Clarke M, Ghersi D, Liberati A, Petticrew $M$, et al. Preferred reporting items for systematic review and meta-analysis protocols (PRISMA-P) 2015 statement. Syst Rev. 2015;4(1):1-19.

14. Cetin Z. A Multivariate Examination of the ChildAbuse Potential of Parents with Children Aged 0-6. 2016;(66):71-86.

15. Ling C, Kwok S. An Integrated Resilience and Ecological Model of Child Abuse (REC-Model). J Child Fam Stud. 2017;26(6):1655-63.

16. Rodriguez CM, Gracia E, Lila M. Multimethod prediction of child abuse risk in an at-risk sample of male intimate partner violence offenders. Child Abuse Negl. 2016;60:27-35.

17. Rodriguez CM, Tucker MC. Predicting Maternal Physical Child Abuse Risk Beyond Distress and Social Support: Additive Role of Cognitive Processes. J Child Fam Stud. 2015;24(6):1780-90.

18. Mikaeili N, Barahmand U, Abdi R. The Prevalence of Different Kinds of Child Abuse and the Characteristics That Differentiate Abused From Nonabused Male Adolescents. J Interpers Violence. 2013;28(5):975-96.

19. Rodriguez CM. Analog of parental empathy: Association with physical child abuse risk and punishment intentions. Child Abuse Negl. 2013;37(8):493-9.

20. Van Vliet-Ruissen C, Mckinlay A, Taylor A. Adult functioning of mothers with traumatic brain injury at high risk of child abuse: A pilot study. NeuroRehabilitation. 2014;34(2):373-80.

21. Ben-David V. A Focus on Neglect: Comparing the Characteristics of Children and Parents in Cases of Neglect, Abuse, and Non-CAN (Child Abuse and Neglect) in Israeli Rulings on Termination of Parental Rights. J Aggress Maltreat Trauma. 2016;25(7):721-40.

22. Douki ZE, Esmaeili MR, Vaezzadeh N, Mohammadpour RA, Azimi H, Sabbaghi R, et al. Maternal child abuse and its association with maternal anxiety in the sociocultural context of Iran. Oman Med J. 2013;28(6):404-9.

23. Zimmer-Gembeck MJ, Thomas R, Hendrickson K, Avdagic E, Webb H, McGregor L. Maternal emotional distress, abuse risk, and children's symptoms: child gender as a moderator of parent sensitivity as a mdiator. Infant Child Dev. 2006;3:3-5.

24. Abdullah M. Prevalence of Family Violence / Child Abuse and its Relationship to Some Variables. Psychol Psychol Res Int J. 2017;2(2):000123.
25. Price-Wolf J. Social Support, Collective Efficacy, and Child Physical Abuse: Does Parent Gender Matter? Child Maltreat. 2015;20(2):125-35.

26. Freisthler B, Gruenewald PJ. Where the Individual Meets the Ecological: A Study of Parent Drinking Patterns, Alcohol Outlets, and Child Physical Abuse. Alcohol Clin Exp Res. 2013;37(6):993-1000.

27. Romero-Martínez A, Figueiredo B, Moya-Albiol L. Childhood history of abuse and child abuse potential: The role of parent's gender and timing of childhood abuse. Child Abuse Negl. 2014;38(3):510-6.

28. Browning CR, Soller B, Gardner M, Brooks-gunn J. "Feeling Disorder" as a Comparative and Contingent Process: Gender, Neighborhood Conditions, and Adolescent Mental Health. J Health Soc Behav. 2013;3(54):296-314.

29. Guterman NB, Lee SJ, Taylor CA, Rathouz PJ. Parental perceptions of neighborhood processes, stress , personal control, and risk for physical child abuse and neglect. Child Abuse Negl. 2009;33:897-906.

30. Milner JS, Chilamkurti C. Physical Child Abuse Perpetrator Characteristics: A Review of the Literature. Hisp J Behav Sci. 1991;9(2):183-205.

31. Santhosh KR, Ph D. A Review on the Perpetrators of Child Abuse. Rev Soc Sci. 2016;01(03):45-52.

32. Gelles RJ. Child Abuse and Violence in Single-Parent Families: Parent Absence and Economic Deprivation. Am J Orthopsychiatry. 1989;59(4):492-501.

33. Brown J, Cohen P, Johnson JG, Salzinger S. A longitudinal analysis of risk factors for child maltreatment: Findings of a 17-year prospective study of officially recorded and self-reported child abuse and neglect. Child Abuse Negl. 1998;22(11):1065-78.

34. Straus MA. Family patterns and child abuse in a nationally representative American sample. Child Abuse Negl. 1979;3(1):213-25.

35. Dym J, Kotake C, Fauth R, Easterbrooks MA. Child Abuse \& Neglect Intergenerational transmission of child abuse and neglect: Do maltreatment type, perpetrator, and substantiation status matter? Child Abuse Negl. 2017;63:84-94.

36. Kaufman J, Zigler E. Do Abused Children Become Abusive Parents? Am J Orthopsychiatry. 1987;57(2).

37. Widom CS, Czaja SJ, DuMont KA. Intergenerational transmission of child abuse and neglect: Real or detection bias? Science. 2015;347(6229):1480-5.

38. Doidge JC, Higgins DJ, Delfabbro P, Segal L. Risk factors for child maltreatment in an Australian populationbased birth cohort. Child Abuse Negl. 2017;64:47-60.

39. Burgess RL, Conger RD. Family Interaction in Abusive, Neglectful and Normal Families. Child Dev. 1978;49(4):1163-73.

40. Reid JB, Taplin PS, Lorber R. A social interactional approach to the treatment of abusive families. In RB Stuart (Ed.), Violent behavior social learning approaches to proneness, management, and treatment. 1981. New York: Brunner/Mazel.

41. Kasim MS, Mohd. Shafie H, Cheah I. Social factors in relation to physical abuse in Kuala Lumpur, Malaysia. Child Abuse Negl. 1994;18(5):401-7. 
42. Belsky J. Three Theoretical Models of Child Abuse : A Critical Review. Child Abuse Negl. 1978;2:37-49.

43. Sampson R, Raudenbush S, Earls F. Neighborhoods and Violent Crime: A Multi-Level Study of Collective Efficacy. Science. 1997;277(5328):918-24.

44. Rodriguez CM, Sutherland D. Predictors of Parents' Physical Disciplinary Practices. Child Abuse Negl. 1999;23:651-7. 